\title{
FICTIONS OF ART HISTORY
}


STUDIES

AISUAI 


\section{FICTIONS \\ OF ART HISTORY}

Edited by Mark Ledbury

Sterling and Francine Clark Art Institute

Williamstown, Massachusetts

Distributed by Yale University Press, New Haven and London 
This publication was conceived by the Research and Academic Program at the Sterling and Francine Clark Art Institute. A related conference, also titled "Fictions of Art History," was held 29-30 October 2010 at the Clark. For information on programs and publications at the Clark, visit www.clarkart.edu.

(C) 2013 Sterling and Francine Clark Art Institute

This book may not be reproduced, in whole or in part, including illustrations, in any form (beyond that copying permitted by Sections 107 and IO8 of the U.S. Copyright Law and except by reviewers for the public press), without written permission from the publisher.

Produced by the Sterling and Francine Clark Art Institute

225 South Street, Williamstown, Massachusetts OI267

Anne Roecklein, Managing Editor

Dan Cohen, Special Projects Editor

Sarah Hammond, Publications Associate

Julie Walsh and Hannah Rose Van Wely, Program Assistants

Copyedited by Audrey Walen

Proofread by June Cuffner

Distributed by Yale University Press, New Haven and London

www.yalebooks.com/art

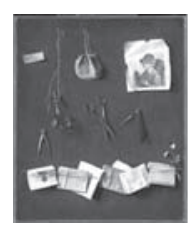

Louis-Léopold Boilly (French, I76I-I845), Various Objects, c. 1785. Oil on canvas, $28^{1 / 2} \times 23^{3 / 4}$ in. $(72.4 \times 60.3 \mathrm{~cm})$. Sterling and Francine Clark Art Institute, Williamstown, Massachusetts

Library of Congress Cataloging-in-Publication Data

Fictions of art history / edited by Mark Ledbury.

pages $\mathrm{cm}$-(Clark studies in the visual arts)

"A related conference, also titled 'Fictions of Art History,' was held 29-30 October 2010 at the Clark." ISBN 978-I-935998-IO-5 (clark pbk. : alk. paper)—ISBN 978-0-300-19192-9 (yale pbk. : alk. paper) I. Art-Historiography-Congresses. 2. Art in literature-Congresses. 3. Fiction-History and criticism-Congresses. I. Ledbury, Mark (Andrew Mark), editor of compilation. II. Fictions of Art History (Conference) (20IO : Sterling and Francine Clark Art Institute)

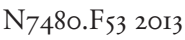

700.72 '2-dc23

2012051140

ISBN 978-O-300-I92I4-8 (e-book) 